\title{
Evaluation of antibacterial and cytotoxic activity of Artemisia nilagirica and Murraya koenigii leaf extracts against mycobacteria and macrophages
}

\author{
Sumanta Kumar Naik, Soumitra Mohanty, Avinash Padhi, Rashmirekha Pati and Avinash Sonawane*
}

\begin{abstract}
Background: Artemisia nilagirica (Asteraceae) and Murraya koenigii (Rutaceae) are widely distributed in eastern region of India. Leaves of Artemisia nilagirica plant are used to treat cold and cough by the local tribal population in east India. Murraya koenigii is an edible plant previously reported to have an antibacterial activity. Pathogenic strains of mycobacteria are resistant to most of the conventional antibiotics. Therefore, it is imperative to identify novel antimycobacterial molecules to treat mycobacterial infection.

Methods: In this study, ethanol, petroleum ether and water extracts of Artemisia nilagirica and Murraya koenigii were tested for antibacterial activity against Mycobacterium smegmatis and Mycobacterium bovis BCG in synergy with first line anti-tuberculosis (TB) drugs, and for cytotoxic activities on mouse macrophage RAW264.7 cells. Antibacterial activity was determined by colony forming unit (CFU) assay. Intracellular survival assay was performed by infecting RAW264.7 cells with M. smegmatis before and after treatment with plant extracts. Cytotoxity was checked by MTT [3-(4,5-Dimethylthiazol-2-yl)-2,5-Diphenyltetrazolium Bromide] assay. Genotoxicity was studied by DAPI staining and COMET assay using mouse macrophage RAW264.7 cell line. Cell apoptosis was checked by Annexin-V/FITC dual staining method. Reactive oxygen species and nitric oxide production was checked by DCFH staining and Griess reagent, respectively.

Results: Ethanol extracts of A. nilagirica $\left({ } C_{50} 300 \mu \mathrm{g} / \mathrm{ml}\right)$ and M. koenigii $\left(I C_{50} 400 \mu \mathrm{g} / \mathrm{ml}\right)$ were found to be more effective against Mycobacterium smegmatis as compared to petroleum ether and water extracts. $M$. koenigii extract showed maximum activity against $M$. bovis BCG in combination with a first line anti-TB drug rifampicin. $M$. koenigii leaf extract also exerted more cytototoxic $\left(\mathrm{IC}_{50} 20 \mathrm{\mu g} / \mathrm{ml}\right)$, genotoxic and apoptosis in mouse macrophage RAW 264.7 cell line. Treatment of mouse macrophages with A. nilagirica extract increased intracellular killing of $M$. smegmatis by inducing production of reactive oxygen species and nitric oxide.
\end{abstract}

Conclusions: Ethanol extracts of A. nilagirica and $M$. koenigii were found to be more effective against mycobacteria. As compared to A. nilagirica, M. koenigii ethanol extract exhibited significant synergistic antibacterial activity against M. smegmatis and $M$. bovis BCG in combination with anti-tuberculosis drug rifampicin, and also showed increased cytotoxicity, DNA damage and apoptosis in mouse macrophages.

Keywords: Tuberculosis, Mycobacteria, Antibacterial activity, Cytotoxicity, Genotoxicity, Artemisia nilagirica, Murraya koenigii

\footnotetext{
* Correspondence: asonawane@kiitbiotech.ac.in

School of Biotechnology, KIIT University, Campus-11, Bhubaneswar, Orissa
}

751024, India 


\section{Background}

The expanding bacterial resistance to antibiotics has become a growing concern worldwide. Mycobacterium tuberculosis (Mtb), the causative agent of tuberculosis (TB), infection represents a major health problem globally. It is estimated that one third of the world's population is infected with $\mathrm{TB}$ and 1 in 10 of them is prone to develop an active TB in their lifetime [1]. Though for several decades TB was successfully treated with a combination of antibiotics, current vaccine and chemotherapeutic measures are limited in their efficacy and are failing to prevent spread of the disease. This problem is further worsened due to the emergence of multi-drug resistant (MDR) and extremely drug-resistant (XDR) Mtb strains that has made most of the front line drugs ineffective, too often impossible, to cure fatal infections [2]. MDR-TB is resistant to the major first line anti-TB drugs isoniazid and rifampicin, while XDR-TB is resistant to any fluoroquinolone, and at least one of three injectable second-line drugs (capreomycin, kanamycin, and amikacin), in addition to isoniazid and rifampicin. It is thus important to identify and develop new molecules that can overcome the limitations of the present drugs and perturb development of antibiotic resistance by mycobacteria.

Increasing bacterial resistance is prompting resurgence in research of the antimicrobial role of herbs against resistant strains. A vast number of medicinal plants have been recognized as valuable resources of natural antimicrobial compounds [3,4]. Medicinal plant extracts offer considerable potential for the development of new agents effective against infections that are currently difficult to treat $[5,6]$. Previous studies have shown that several substances such as peptides, unsaturated long chain aldehydes, essential oils and alkaloid constituents of plant extracts have potential therapeutic properties [7]. Therefore, assessment of such plants remains an interesting and useful task to find new promising agents against bacterial infections. In case of TB, the first drug streptomycin was developed in 1947 and later on isoniazid, pyrazinamide and ethambutol were introduced, and then in 1960's rifampicin, which till today is considered as the cornerstone of first-line TB drugs. Since then the development of anti-TB drugs has faltered. In the last few decades, though a large number of drugs have been discovered, many of them failed to kill drug resistant bacteria effectively. Moreover, mycobacterium has a lipid rich cell wall, which prevents binding and diffusion of most of the drugs [8]. Therefore, there is a need to identify molecules that will act directly on the cell wall of mycobacteria to achieve effective killing.

Artemisia nilagirica, which belongs to family Asteraceae, and Murraya koenigii belonging to family Rutaceae are well distributed in eastern region of India. Previously the leaf extract of $A$. nilagirica has been reported with an antibacterial activity [9]. The leaves of this plant are also used against cold and cough by the local tribal population in east India. M. koenigii is an edible plant. Compounds like mahanine, mahanimbicine and mahanimbine from $M$. koenigii plant are reported to have antibacterial activity against Staphylococcus aureus, Pseudomonas aeruginosa, Klebsiella pneumoniae, Escherichia coli and Streptococcus pneumoniae [10,11].

The main objective of this work was to identify plants with antimycobacterial activity. Here we have screened several leaf extracts prepared from Eupatorium triplinerve, Nyctanthes arbortristis, Azadirachta indica, Barringtonia acutangula, Achyranthes aspera, Moringa oleifera, Artemisia nilagrica, Murraya koenigii, Lantana camara, Mentha spicata for their antimycobacterial activity. These plants were selected on the basis of their reported edible or medicinal properties by local tribal population of eastern India. Among them, A. nilagirica $\left(\mathrm{IC}_{50} 300 \mu \mathrm{g} / \mathrm{ml}\right.$ ) and M. koenigii $\left(\mathrm{IC}_{50} 400 \mu \mathrm{g} / \mathrm{ml}\right)$ ethanol leaf extracts were found to be more effective against M. smegmatis and $M$. bovis BCG. Ethanol extract of $M$. koenigii showed increased antibacterial activity against $M$. bovis BCG in synergy with an anti-TB drug rifampicin. Ex vivo studies showed that $A$. nilagirica extract is able to kill intracellular M. smegmatis in macrophages by inducing the production of reactive oxygen species (ROS) and nitric oxide (NO). Toxicity studies showed that $M$. koenigii ethanol extract exhibit more cytotoxic and genotoxic activities and also induced more apoptosis in mouse macrophage RAW264.7 cell line, which indicates presence of both antimycobacterial and cytotoxic compounds in the extract.

\section{Methods}

\section{Preparation of plant extract}

All the plants were identified by Dr. Udhab Behera from Regional Plant Resource Centre, Odisha and these plants have been deposited in the herbarium at Regional Plant Resource Centre, Keonjhar, Odisha, India. Leaves of $A$. nilagirica (KCCP/2013/AN/102) and M. koenigii (KCCP/ 2013/MK/101) were collected from forests of North Odisha region, India. Leaves were first washed thoroughly to remove impurities, shade dried and then ground to fine powder. To prepare extract, leaf powder (10 gm dry weight) was extracted with $50 \mathrm{ml}$ of absolute ethanol and kept on shaker for 48 hours. The extract was then centrifuged at $2300 \mathrm{~g}$ (3-30 K, Sigma) for 20 minutes and supernatant was collected. Solvent was removed with the help of rotary evaporator and stored at $-20^{\circ} \mathrm{C}$. Extract was dissolved in 1\% DMSO (wt/vol) for further use [12].

\section{Cell lines and bacterial culture conditions}

Mycobacterium smegmatis $\mathrm{mc}^{2} 155$ and M. bovis BCG Pasteur (ATCC35734) strains were grown in Middlebrook's 
7H9 broth medium (Difco) supplemented with $10 \%$ OADC (Oleic acid-albumin dextrose-catalase) and 0.05\% tween 80 (Merck) at $37^{\circ} \mathrm{C}$ and $120 \mathrm{rpm}$. The mouse macrophage cell line RAW264.7 was cultured in DMEM supplemented with $10 \%$ fetal calf serum (FCS), $1 \%$ penicillin-streptomycin solution, $1 \%$ L-glutamine and HEPES.

\section{In vitro killing assay}

To determine the antibacterial activity of plant extracts, the overnight grown cultures were centrifuged at $2300 \mathrm{~g}$ for 5 minutes, washed with $1 \mathrm{X}$ PBS and the pellet was suspended in 7H9 broth medium. Finally the optical density (O.D.) of the sample was adjusted to 0.1 at $600 \mathrm{~nm}$ that corresponds to $1 \times 10^{7} \mathrm{cfu} / \mathrm{ml}$ [13]. Various concentrations of plant extracts were incubated with $4-5 \times 10^{5}$ bacteria in $7 \mathrm{H} 9$ media. Medium with bacteria and $1 \%$ DMSO only were used as controls. Bacteria were harvested at $24 \mathrm{~h}$ time point and the number of colony forming units (CFUs) was assayed by plating serially diluted samples on $7 \mathrm{H} 9$ medium. The colonies were counted after $72 \mathrm{~h}$ and 3 weeks for M. smegmatis and $M$. bovis BCG, respectively.

To check the synergistic activity of plant extract and anti-TB drugs, IC50 values of rifampicin $(0.7 \mu \mathrm{g} / \mathrm{ml})$ and isoniazid $(7.5 \mu \mathrm{g} / \mathrm{ml})$ were determined by CFU assay and their synergistic antimycobacterial activity was checked with different concentrations (200 and $400 \mu \mathrm{g} / \mathrm{ml}$ ) of plant extracts.

\section{Isobologram analysis}

Isobologram analysis was performed to check the combinational effect of $M$. koenigii and rifampicin. IC50 values obtained from M.koeingii $(400 \mu \mathrm{g} / \mathrm{ml})$ and rifampicin $(0.7 \mu \mathrm{g} / \mathrm{ml})$ were analyzed by joining the data points with a line. The IC50 value from the combinatorial treatment was also plotted on the same plot. Isobologram analysis considered the data additive if the data point falls on the line, synergistic interaction appears below the line, and an antagonistic interaction appears above the line [14].

\section{Cytotoxic effect of plant extracts on mouse macrophage RAW264.7}

To determine the cytotoxic activity of plant extracts on macrophages, RAW264.7 in DMEM were grown in a 96 well plate $\left(10,000\right.$ cells per well) at $37^{\circ} \mathrm{C}, 5 \% \mathrm{CO}_{2}$ for 24 hours followed by treatment with different concentrations of plant extracts for another 24 hours. Cells were washed with $1 \mathrm{X}$ PBS before addition of MTT. To determine the cell viability, MTT at a concentration of $0.1 \mu \mathrm{g} / \mathrm{ml}$ was added to the wells and incubated for 4 hours at $37^{\circ} \mathrm{C}$ and $5 \% \mathrm{CO}_{2}$ in dark condition. In metabolically active cells, MTT reduced to purple color insoluble formazan crystal. Formazan crystals were dissolved in dissolving buffer (11gm SDS in $50 \mathrm{ml}$ of $0.02 \mathrm{M} \mathrm{HCl}$ and $50 \mathrm{ml}$ isopropanol). The absorbance was read at $570 \mathrm{~nm}$ in ELISA reader (Biotek, Germany), compared with the untreated cells and percentage of viable cells was calculated as described previously [15].

\section{Apoptosis assay}

The percentage of apoptotic cells was determined by using an Annexin V-FITC apoptosis detection kit (Sigma) as described previously [16]. Briefly, $2 \times 10^{5}$ RAW264.7 cells per well were grown overnight in a six-well culture plate, treated with various concentrations of plant extracts and the cells were incubated for another $12 \mathrm{~h}$. The cells were treated with trypsin, washed three times with Dulbecco's phosphate buffer saline (0.1 M, pH 7.4) and $500 \mu \mathrm{l}$ of $1 \mathrm{X}$ binding buffer was added, followed by $5 \mu \mathrm{l}$ of annexin $\mathrm{V}$ FITC and $10 \mu \mathrm{l}$ of propidium iodide, and then incubated for $10 \mathrm{~min}$ at room temperature in the dark. Untreated cells were taken as a negative control. Flow cytometry was performed by analyzing 10,000 gated cells using a FACSCalibur flow cytometer and CellQuest software (Becton Dickinson, USA).

\section{Comet assay}

The effect of plant extracts on DNA damage was determined by alkaline single cell electrophoresis (Comet) assay. In 6-well cell culture plate, $5 \times 10^{5}$ RAW264.7 macrophages per well were treated with $M$. koenigii $(100 \mu \mathrm{g} / \mathrm{ml})$ and $A$. nilagirica $(300 \mu \mathrm{g} / \mathrm{ml})$ extracts for $12 \mathrm{~h}$ [17]. These concentrations were found to be effective against $M$. smegmatis under in vitro killing assay. Untreated cells were used as control. Cells were treated with trypsin and a cell suspension (5000 cells/ $\mu \mathrm{l})$ was prepared in $1 \mathrm{X}$ phosphate-buffered saline (PBS). Then, $10 \mu \mathrm{l}$ of cell suspension was mixed with $60 \mu \mathrm{l}$ of $0.5 \%$ low-melting point agarose. A thin smear of cell suspension was prepared in glass cavity slides (Blue Label Scientifics, Mumbai, India). The agarose was allowed to solidify in the dark at $4^{\circ} \mathrm{C}$ for $45 \mathrm{~min}$, and then the slides were submerged in lysis solution (10 mM Tris, $100 \mathrm{mM}$ EDTA, $2.5 \mathrm{M} \mathrm{NaCl}, 1 \%$ Triton-X-100, 10\% dimethyl sulfoxide) for $30 \mathrm{~min}$ in dark at $4^{\circ} \mathrm{C}$. After lysis, the slides were washed with distilled $\mathrm{H}_{2} \mathrm{O}$, transferred to an electrophoresis unit containing freshly prepared electrophoresis buffer (500 mM EDTA, $200 \mathrm{mM} \mathrm{NaOH}, \mathrm{pH} 13.0$ ), left for unwinding of DNA for $45 \mathrm{~min}$, and the cells were electrophoresed for $15 \mathrm{~min}$ at $15 \mathrm{~V}$. The cells were washed twice with $\mathrm{dH}_{2} \mathrm{O}$, fixed with $70 \%$ chilled ethanol, and stained with $0.5 \mu \mathrm{g}$ of propidium iodide/ $\mathrm{ml}$ for $15 \mathrm{~min}$ in dark. The slides were dried and observed using a fluorescence microscope (Nikon, Japan). 


\section{Effect on intracellular killing of mycobacteria}

To examine whether treatment with plant extracts increase killing efficiency of macrophages, $5 \times 10^{5}$ RAW264.7 cells were treated with $A$. nilagirica extract $2 \mathrm{~h}$ before and after M. smegmatis infection at an multiplicity of infection of 10 termed as "pretreated" and post-treated", respectively as described previously [13]. Then the cells were washed with 1X PBS and extracellular bacteria were killed by addition of $20 \mu \mathrm{g} / \mathrm{ml}$ of gentamicin for $1 \mathrm{~h}$. Macrophages infected with bacteria alone were used as a control. After $6 \mathrm{~h}$ incubation period, cells were washed and lysed with $0.5 \%$ triton $\mathrm{X}-100$. The intracellular survival was determined by plating serially diluted cultures on 7H10 medium and the colonies were enumerated after 3 days.

\section{Determination of ROS production}

Generation of ROS in RAW264.7 was determined by using 2', 7'-dichlorofluorescin diacetate (DCFH-DA), a lipid-permeable non-fluorescent compound that when oxidized by intracellular ROS in the presence of cellular esterase, forms the fluorescent compound 2', 7'-dichlorofluorescein (DCF). RAW264.7 cells $\left(2 \times 10^{5}\right)$ were seeded on 24-well tissue culture plate. After $24 \mathrm{~h}$, the cells were treated with different concentrations of $A$. nilagirica. Untreateded cells were used as control. After $24 \mathrm{~h}$ of treatment, media was removed and DMEM containing $10 \mu \mathrm{M}$ DCFH-DA was added to the cells and incubated at $37^{\circ} \mathrm{C}$ and $5 \% \mathrm{CO}_{2}$ for $4 \mathrm{~h}$. Then the DCFH-DA containing medium was removed and the cells were rinsed with $1 \mathrm{X}$ PBS and the fluorescence intensity of DCF was measured using 10,000 gated cells by flowcytometer BD FACS Canto-II and FACS Diva software as described previously [18].

\section{Determination of NO production}

NO production was determined by using Griess reagent. RAW264.7 cells were treated with different concentrations $(100-400 \mu \mathrm{g} / \mathrm{ml})$ of plant extracts for $24 \mathrm{~h}$. Supernatant was collected and $100 \mu \mathrm{l}$ of each of them was added in triplicate in a 96-well plate. $\mathrm{NaNO}_{2}$ solution $(0-200 \mu \mathrm{M})$ was used as a standard. $100 \mu \mathrm{l} /$ well of the Griess reagent $(6 \mathrm{mg} / \mathrm{ml})$ was added to the samples and the reaction products were estimated colorimetrically at $550 \mathrm{~nm}[19]$.

\section{Statistical analysis}

Statistically significant differences between groups were determined using Mann Whitney test. Significance was referred as $*$ for $\mathrm{P} \leq 0.0005$ and $*$ for $\mathrm{P} \leq 0.01$.

\section{Results}

Antibacterial activity of plant extracts

Several plant leaf extracts, Eupatorium triplinerve, Nyctanthes arbortristis, Azadirachta indica, Barringtonia acutangula, Achyranthes aspera, Moringa oleifera, Artemisia nilagrica, Murraya koenigii, Lantana camara, Mentha spicata were screened for anti-mycobacterial activity. These plants were identified by Dr. Udhab Behera, Regional Plant Resource Centre, Odisha, India. These plants have been deposited in the herbarium at Regional Plant Resource Centre, Keonjhar, Odisha, India. Extracts were prepared using petroleum ether, ethanol and water solvents. Among above mentioned plants, only ethanol extracts of $A$. nilagirica and $M$. koenigii showed antibacterial activity against $M$. smegmatis, as determined by CFU assay. However, extracts prepared using petroleum ether and water did not show any anti-mycobacterial activity (data not shown). As shown in Figure 1, ethanol leaf extracts of $M$. koenigii and $A$. nilagirica showed significant antibacterial activity at $400 \mu \mathrm{g} / \mathrm{ml}(\mathrm{P} \leq 0.0005$; Figure $1 \mathrm{~A})$ and $200 \mu \mathrm{g} / \mathrm{ml}(\mathrm{P} \leq 0.0005$; Figure $1 \mathrm{C})$ concentrations against $M$. smegmatis, respectively. However, $M$. bovis BCG was found to be resistant to both the plant extracts under similar conditions (Figure 1B and 1D). As the ethanol extract showed more antibacterial activity following experiments were performed with $M$. koenigii and A. nilagirica ethanol extracts only.

\section{Synergistic antibacterial activity of plant extracts and anti-TB drugs}

As $M$. bovis BCG showed resistance to both the plant extracts, we checked whether addition of anti-TB drugs rifampicin and isonizid to plant extracts can enhance the bacterial killing. For this, first IC50 values of rifampicin and isoniazid against $M$. smegmatis were determined. The values were determined as $0.7 \mu \mathrm{g} / \mathrm{ml}$ and $7.5 \mu \mathrm{g} / \mathrm{ml}$ for rifampicin and isoniazid, respectively (data not shown). M. smegmatis was incubated with different concentrations of plant extracts containing rifampicin $(0.7 \mu \mathrm{g} / \mathrm{ml})$ and isoniazid $(7.5 \mu \mathrm{g} / \mathrm{ml})$. M. koenigii $(\mathrm{MK})$ extract showed synergistic activity with rifampicin $(\mathrm{P} \leq 0.0005, \mathrm{P} \leq 0.01$; Figure 2A) such that no viable bacteria were observed in presence of rifampicin and $400 \mu \mathrm{g} / \mathrm{ml}$ of $M$. koenigii extract, whereas in presence of $\mathrm{MK}$ and rifampicin alone significantly higher bacterial count was observed. Isobologram analysis showed that the data point for the combination of $M$. koenigii (MK) and rifampicin(RIF) falls below the line, indicating synergistic activity (Figure 2B). No synergistic activity was observed with isoniazid (Figure 2C). As MK extract showed synergistic activity with rifampicin, we checked their activity against $M$. bovis BCG. No viable colonies were observed in presence of a combination of MK and rifampicin, whereas significantly higher bacterial colonies were observed in presence of MK extract and rifampicin alone $(\mathrm{P} \leq 0.01$; Figure $2 \mathrm{D})$. In contrast, $A$. nilagirica (AN) extract did not show any synergistic activity with both rifampicin and isoniazid $(\mathrm{P} \leq 0.0005, \mathrm{P} \leq 0.01$; Figure $3 \mathrm{~A}$ and $3 \mathrm{~B}$ ). 

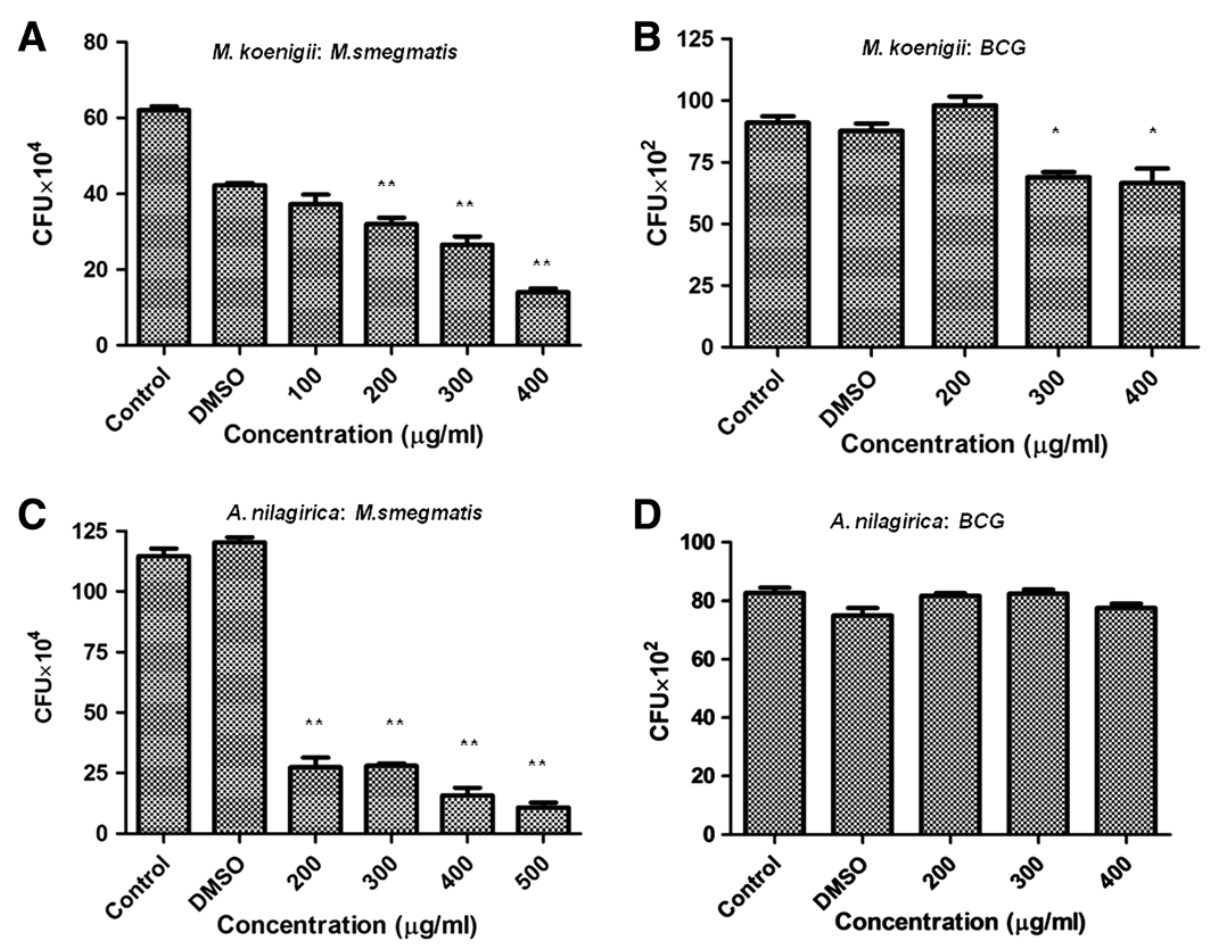

Figure 1 Antibacterial activity of $M$. koenigii and A. nilagirica ethanol leaf extracts against $M$. smegmatis and $M$. bovis BCG. $4-5 \times 10^{5} M$. smegmatis $(\mathbf{A}, \mathbf{C})$ and $M$. bovis $B C G(B, D)$ were incubated with different concentrations of $M$. koenigii and $A$. nilagirica ethanol leaf extracts for $24 \mathrm{~h}$ in $7 \mathrm{H} 9$ medium and the number of colony forming units were counted after $72 \mathrm{~h}$ and 3 weeks for $\mathrm{M}$. smegmatis and M.bovis BCG, respectively by plating serially diluted samples on $7 \mathrm{H} 9$ medium. Media containing bacteria alone was used as control. Experiments were performed in triplicates, means \pm the standard deviation (SD) are shown. ${ }^{*}, \mathrm{P} \leq 0.0005 ;{ }^{*}, \mathrm{P} \leq 0.01$.

\section{Cytotoxic and genotoxic effect of plant extracts on mouse macrophages}

The cytotoxic effect of plant extracts on macrophages was determined by MTT assay, which relies on the fact that metabolically active cells reduce MTT to purple formazan. As shown in Figure 4, M. koenigii extract exhibited more cytotoxicity such that at $20 \mu \mathrm{g} / \mathrm{ml}$ concentration approximately $50 \%$ reduction in cell viability was observed ( $\mathrm{P} \leq 0.0005$; Figure $4 \mathrm{~A})$. In case of $A$. nilagirica, $50 \%$ reduction in cell viability was observed at $500 \mu \mathrm{g} /$ $\mathrm{ml}$ (Figure 4B). These data indicated that $M$. koenigii is more cytotoxic as compared to $A$. nilagirica.

We also examined the RAW264.7 morphology in a monolayer culture after treatment with different concentrations of plant extracts. Microscopic observations showed that treatment with $100 \mu \mathrm{g} / \mathrm{ml}$ of $M$. koenigii extract disintegrated the cell morohology. In case of $A$. nilagirica no distinct morphological changes were observed at same concentration, however cells appeared slightly rounded at $300 \mu \mathrm{g} / \mathrm{ml}$ concentration (Figure $4 \mathrm{C}$ ).

For genotoxic studies, RAW264.7 cells were treated with $M$. koenigii $(100 \mu \mathrm{g} / \mathrm{ml})$ and A. nilagirica $(300 \mu \mathrm{g} / \mathrm{ml})$ extracts. Nuclear integrity and DNA damage was studied by DAPI and comet assays. Nuclear fragmentation and comet like tail, which implies DNA damage, was observed in $M$. koenigii treated macrophages, whereas no such DNA damage was observed in A. nilagirica treated cells (Figure 4D and 4E).

\section{Cell apoptosis}

To examine the nature of cell death, annexin-V-FITC/PI dual staining assay was performed according to the manufacturer's instruction. The dual staining method differentiates early apoptotic (annexin-V positive, PI negative), late apoptotic (both annexin-V and PI positive), necrotic (only PI positive) and healthy viable cells (both annexin-V and PI negative) based on the staining pattern. RAW264.7 cells were treated with $M$. koenigii (10 and $100 \mu \mathrm{g} / \mathrm{ml})$ and A. nilagirica (10 and $300 \mu \mathrm{g} / \mathrm{ml}$ ) extracts for $24 \mathrm{~h}$. The data showed that more than $80 \%$ cells were viable after treatment with $10 \mu \mathrm{g} / \mathrm{ml}$ concentration of $\mathrm{M}$. koenigii, while at $100 \mu \mathrm{g} / \mathrm{ml}$ concentration more than $80 \%$ cells were found to be necrotic (Figure 5A). In comparison, no apoptosis was observed after treatment with $10 \mu \mathrm{g} /$ $\mathrm{ml}$ concentration, and significantly less (10\%) apoptosis was induced after treatment with $300 \mu \mathrm{g} / \mathrm{ml}$ of $A$. nilagirica extract. 

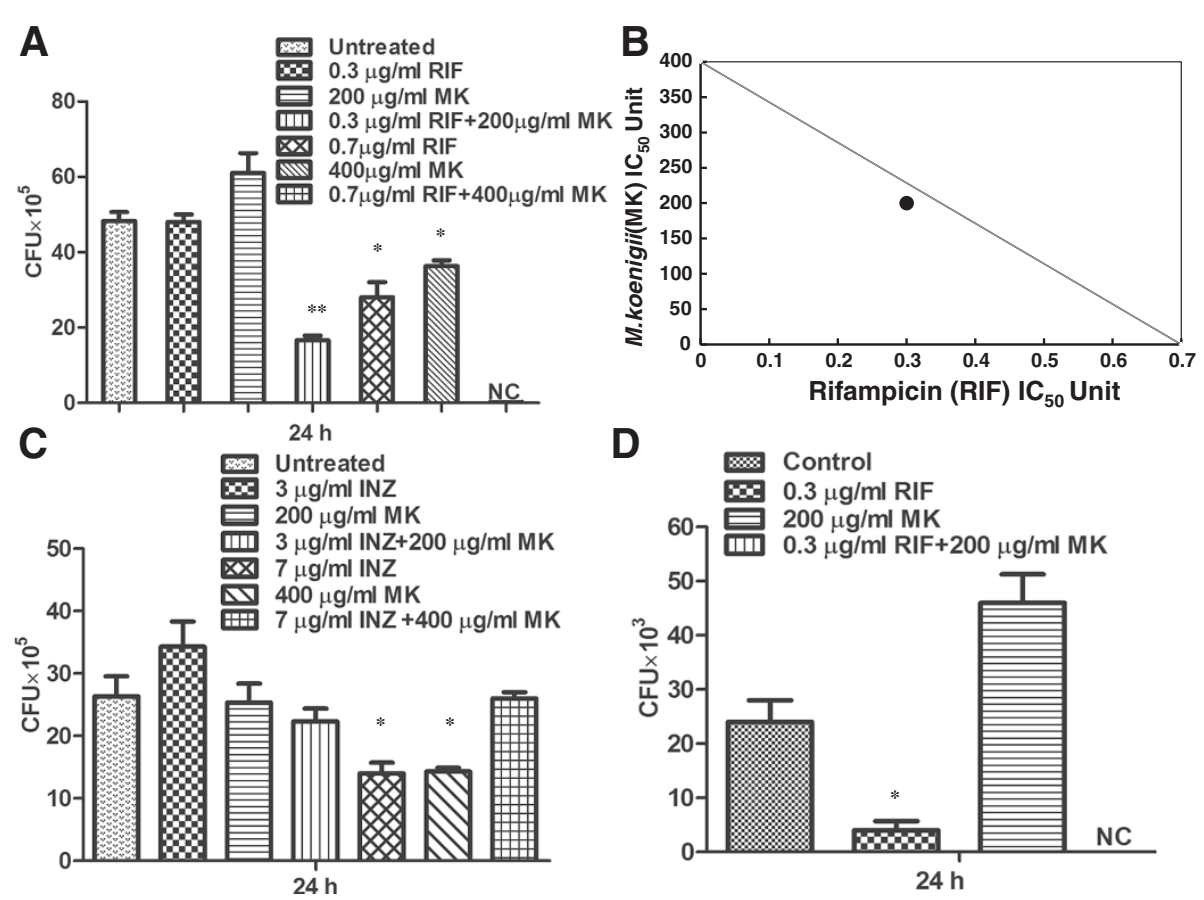

Figure 2 Synergistic antibacterial activity of $\boldsymbol{M}$. koenigii (MK) ethanol leaf extract and first-line anti-TB drugs. (A) M. smegmatis was incubated with MK extract ( 200 and $400 \mu \mathrm{g} / \mathrm{ml}$ ) alone or in combination with rifampicin (RIF) $(0.3$ and $0.7 \mu \mathrm{g} / \mathrm{ml})$ for $24 \mathrm{~h}$. The number of CFUs were counted after $72 \mathrm{~h}$ of incubation. Data showed decreased bacterial count in presence of both MK and RIF. (B) Isobologram analysis of MK extract and RIF. The data point falls below the line indicating syngergistic activity. (C) M. smegmatis was incubated with MK extract and isoniazid (INZ) for 24 hours and numbers of CFUs were assayed. (D) M. bovis BCG was incubated with MK extract ( $200 \mu \mathrm{g} / \mathrm{ml})$ and rifampicin (RIF) ( $0.3 \mu \mathrm{g} / \mathrm{ml})$ for 24 hours and numbers of CFUs were assayed after 3 weeks. Media containing bacteria alone was used as control. NC means no colonies. Experiments were performed in triplicates, means \pm the $S D$ are shown. ${ }^{*}, P \leq 0.0005 ;{ }^{*}, P \leq 0.01$.

\section{Intracellular killing of mycobacteria in extract treated macrophages}

As $A$. nilagirica leaf extract was found to be less cytotoxic, we treated RAW264.7 cells with $A$. nilagirica leaf extract to check the intracellular killing of mycobacterium. We hypothesized that the extract may stimulate macrophages, which will lead to intracellular killing of mycobacteria. To study this, cells were infected with $M$. smegmatis two hours before and after infection termed as "pretreated" and post-treated", respectively. After 6 hour of treatment we found that the intracellular bacterial burden was significantly less in pretreated cells in compared to post treated cells (Figure 5B).

\section{Treatment with $A$. nilagirica extract induce superoxide} radical production in macrophages

Mycobacterium tuberculosis persists in macrophages for extended period of time. However, upon activation
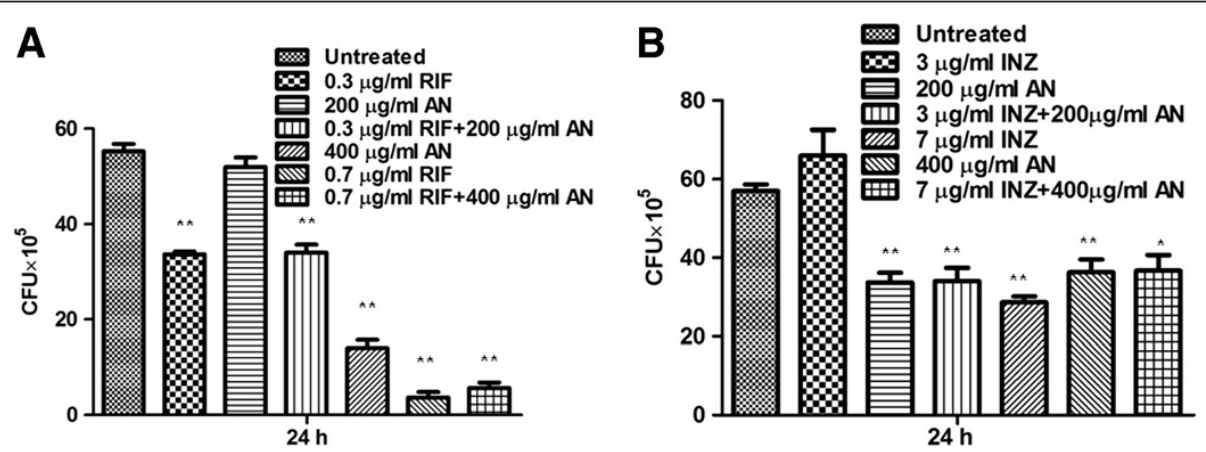

Figure 3 Synergistic anti-bacterial activity of $A$. nilagirica (AN) ethanol leaf extract and first-line anti-TB drugs. M. smegmatis was incubated with (A) AN extract and rifampicin (RIF) (B) AN extract and isoniazid (INZ) for 24 hours and number of CFUs were assayed. Data showing no synergism of $A$. nilagirica with either of the drugs. Media containing bacteria alone was used as control. Experiments were performed in triplicates, means \pm the $S D$ are shown. ${ }^{* *}, P \leq 0.0005 ;{ }^{*}, P \leq 0.01$. 


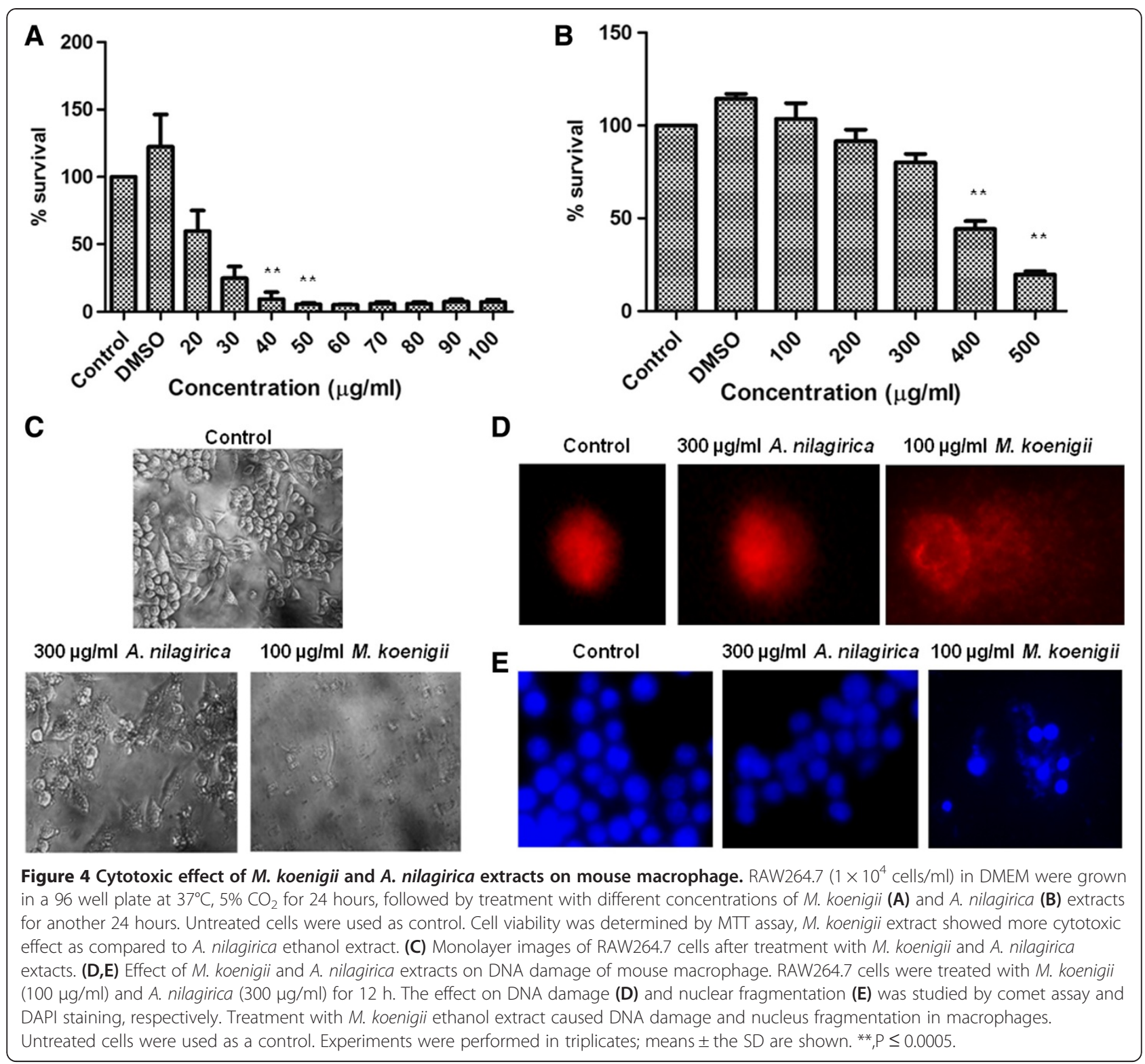

macrophages kill intracellular mycobacteria by the production of superoxide radicals such as ROS, reactive nitrogen species (RNS) and nitric oxide (NO). It was observed that treatment with $A$. nilagirica leaf extract induced the production of NO (Figure $5 \mathrm{C}$ ) and ROS (Figure 5D) as compared to control cells. These results indicate that the antibacterial activity of $A$. nilagirica leaf extract may be due to inducing the oxidative stress by increasing the production of ROS and NO.

\section{Discussion}

Treatment of drug resistant mycobacterial strains has become a major problem worldwide. The hydrophobic nature of Mycobacterium tuberculosis cell wall prevents binding and diffusion of drugs [20]. Moreover, the cell wall of pathogenic mycobacteria contains many efflux pumps, which expels the drugs rapidly before they reach to the site of action [21]. These two, along with several other factors [22], play a decisive role in the development of resistance in mycobacteria. In this study edible and medicinally important plants, few of them are used for the treatment of several diseases by local tribal populations of India, were screened for their anti-mycobacterial activity. Ethanol extracts prepared from M. koenigii and A. nilagirica plants showed significant antimycobacterial activity. Previous studies have reported anti-inflammatory, anti-bacterial, anti-tumor activities of $M$. koenigi extracts $[23,24]$. Koenimbine, mahanimbine, mahanine and 


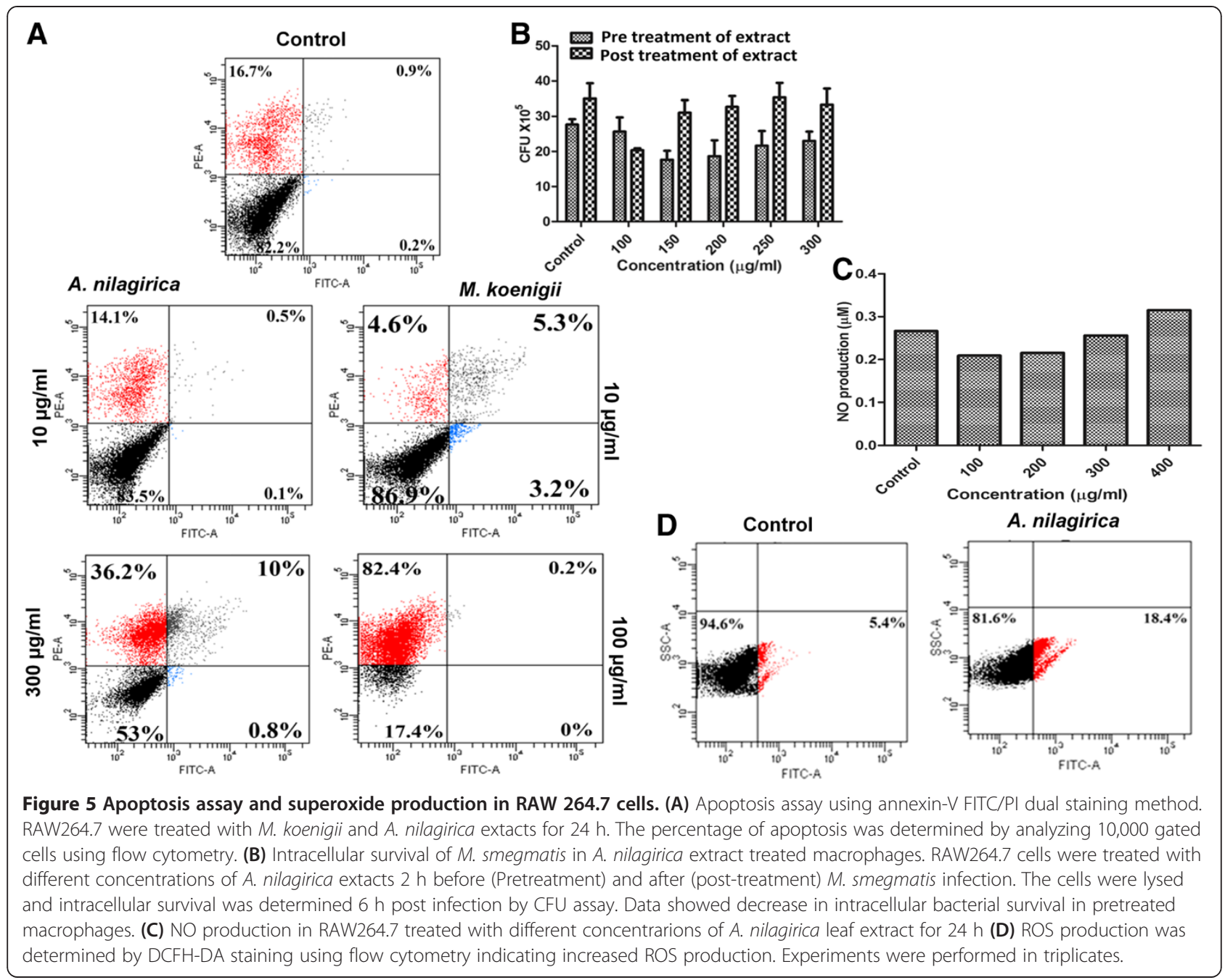

mahanimboline present in $M$. koenigi extract showed antidiarrhea and antibacterial activities [25,26]. A. nilagirica has been reported to exhibit insecticidal and antibacterial activities [27]. Around 59 compounds were identified from $A$. nilagirica which showed an inhibitory activity against phytopathogens like Xanthomonas campestris, Pseudomonas syringae, Clavibacter michiganense [28].

In vitro killing assay using ethanol extracts of $M$. koenigi and $A$. nilagirica showed a significant level of inhibition against $M$. smegmatis. On the other hand, petroleum ether and water extracts did not show any antibacterial activity indicating that antimycobacterial compounds are mainly present in ethanol extract. The in vitro antibacterial assay showed that $A$. nilagirica extract is more active against $M$. smegmatis. Previously, phytochemical analysis of $A$. nilagirica ethanol extract showed the presence of alkaloids, phenolic, quinines and saponins, all of which have been shown to possess antimicrobial activity [28]. Distinct differences in the susceptibility to both plant extracts were observed. M. smegmatis was found to be more susceptible, whereas the mycobacterial vaccine strain, $M$. bovis BCG showed resistance to both plant extracts. This may due to structural and compositional differences in the cell wall of two groups, which limits the diffusion of drugs inside the bacterial cell. However, treatment with a combination of rifampicin and M. koenigii extract led to increased killing of BCG. Rifampicin kills mycobacteria by binding to the $\beta$ subunit of the RNA polymerase thus interfere in the RNA synthesis. So treatment with $M$. koenigii extract might have facilitated the transport of rifampicin inside the mycobacterial cell by altering cell membrane permeability and thereby killing of mycobacteria by inhibiting RNA synthesis.

Cytotoxic and genotoxic studies showed that $M$. koenigii is more toxic to the mouse macrophages. It was found that with increasing concentrations, percentage of cell viability decreased. This cytotoxic effect could be due to presence of alkaloids in the M. koenigii extract. Previous 
studies have shown that mahanimbine, mahanine, mahanimbicine alkaloids present in $M$. koenigii extract exhibit cytotoxic activity against MCF-7, P388 and HeLa cell lines [11]. This could also be attributed to higher production of oxygen radicals, disintegration of membrane integrity and cytoskeletal functions as a result of treatment. Microscopic studies also showed that treatment with $M$. koenigii extract disintegrated the cell morphology. Selectivity index (SI) is calculated as: $\mathrm{SI}=$ Ratio of toxicity to activity $=\mathrm{IC50} / \mathrm{MIC}$. For A. nilagirica, SI $=500 / 200=2.5$ and for $M$. koenigii, $\mathrm{SI}=20 / 400=0.05$. More SI value indicates more selectivity for bacteria and less cytotoxic for cell line. Selective index of ethanol extracts of M. koenigii is less than $A$. nilagirica ethanol extract, which indicates that ethanol extract of $M$. koenigii is less selective for M. smegmatis as compared to A. nilagirica and toxic for RAW264.7 cell line.

The comet assay showed significant increase in tail length, which manifests DNA damage, after treatment with $M$. koenigii extract, whereas treatment with $A$. nilagirica did not show any effect. It has been observed that exposure to plant extracts lead to an increase in DNA damage and necrosis [29].

No cell apoptosis was observed at the lower dose $(10 \mu \mathrm{g} / \mathrm{ml})$, whereas treatment with higher dose of $M$. koenigii $(100 \mu \mathrm{g} / \mathrm{ml})$ resulted in an increase in the number of apoptotic cells. In contrast, significantly less apoptosis was observed in $A$. nilagirica extract treated cells. The increased DNA damage and apoptosis at higher doses could also be due to increased production of reactive oxygen species (ROS). It has been reported that increased ROS production caused genotoxic effect in fibroblast cells [30], which may lead to cell apoptosis.

Since mycobacteria are an intracellular pathogen [31,32], which resides in phagosomal compartment of macrophages, it is important to activate the macrophages or deliver the therapeutic molecules to the target sites that would kill the intracellular mycobacteria. Exogenous addition of $A$. nilagirica extract found to kill intracellular M. smegmatis, Macrophages kill mycobacteria by inducing the ROS and NO production. We observed increased ROS and NO production in macrophages after treatment with $A$. nilagirica extract. Hence the observed killing effect could be due to formation of superoxide radicals and activation of macrophages. Treatment with plant extract also induces the production of pro-inflammatory cytokines [33], which activate the cells resulting in an increase in killing efficiency of macrophages.

\section{Conclusions}

Here we have shown that ethanol extracts of $M$. koenigii and A. nilagirica exhibit high inhibitory potency against $M$. smegmatis and that $M$. koenigii extract in synergy with rifampicin killed $M$. bovis BCG efficiently. M. koenigii extract was found to be more cytotoxic and genotoxic to mouse macrophages, whereas $A$. nilagirica extract killed intracellular mycobacteria without exhibiting any toxic effect on macrophages. The intracellular killing could be due to increased ROS and NO production. This will help in development of natural antimicrobials to decrease the side effects of synthetic drugs. Investigation on fractionation and characterization of these active compounds from both plant extracts is under way.

\section{Abbreviations \\ MK: Murraya koenigii; AN: Artemisia nilagirica.}

\section{Competing interests}

The authors have no conflict of interests.

\section{Authors' contributions}

SKN carried out the leaf extraction, antibacterial assay, analyzed the data and drafted the manuscript. AP and RP carried out the cell culture and microscopy experiments. SM performed apoptosis assay and participated in the design of the study and performed the statistical analysis. AS conceived of the study, and participated in its design and coordination and wrote the manuscript. All authors read and approved the final manuscript.

\section{Acknowledgements}

We would like to thank Sonawane lab members for fruitful suggestions and discussions. This work was supported by grant (SR/NM/NS-1085/2011) from Department of Science and Technology, Government of India to AS.

Received: 30 October 2013 Accepted: 25 February 2014

Published: 5 March 2014

\section{References}

1. Bishai JD, Bishai WR, Bishai DM: Heightened vulnerability to MDR-TB epidemics after controlling drug-susceptible TB. PLOS ONE 2010, 5(9):e12843.

2. Skrahina A, Hurevich H, Zalutskaya A, Sahalchyk E, Astrauko A, van Gemert W, Hoffner S, Rusovich V, Zignol M: Alarming levels of drug-resistant tuberculosis in Belarus: results of a survey in Minsk. Eur Respir J 2012, 39:1425-1431.

3. Ríos $\mathrm{J}$, Recio MC: Medicinal plants and antimicrobial activity. J Ethnopharmacol 2005, 100(1-2):80-84.

4. Kokoska L, Polesny Z, Rada V, Nepovim A, Vanek T: Screening of some Siberian medicinal plants for antimicrobial activity. J Ethnopharmacol 2002, 82(1):51-53.

5. Khan R, Islam B, Akram M, Shakil S, Ahmad A, Ali SM, Siddiqui M, Khan AU: Antimicrobial activity of five herbal extracts against multi drug resistant (MDR) strains of bacteria and fungus of clinical origin. Molecules 2009, 14(2):586-597.

6. Adeniyi BA, Groves MJ, Gangadharam PRJ: In vitro anti-mycobacterial activities of three species of Cola plant extracts (Sterculiaceae). Phytother Res 2004, 18(5):414-418.

7. Cowan MM: Plant products as antimicrobial agents. Clin Microbiol Rev 1999, 12(4):564-582.

8. Ojha AK, Baughn AD, Sambandan D, Hsu T, Trivelli X, Guerardel Y, Alahari A, Kremer L, Jacobs WR Jr, Hatfull GF: Growth of Mycobacterium tuberculosis biofilms containing free mycolic acids and harbouring drug-tolerant bacteria. Mol Microbiol 2008, 69(1):164-174.

9. Ahameethunisa AR, Waheeta $\mathrm{H}$ : Antibacterial activity of Artemisia nilagrica leaf extracts against clinical and phytopathogenic bacteria. BMC Complementary \& Alternative medicine 2010, 10:6.

10. Meléndez PA, Capriles VA: Antibacterial properties of tropical plants from Puerto Rico. Phytomedicine 2006, 13:272-276.

11. Nagappan T, Ramasamy P, Wahid ME, Segaran TC, Vairappan CS: Biological activity of carbazole alkaloids and essential Oil of Murraya koenigii against antibiotic resistant microbes and cancer cell lines. Molecules 2011, 16:9651-9664

12. Luize PS, Tiuman TS, Morello LG, Maza PK, Nakamura TU, Filho BPD, Cortez DAG, de Mello JCP, Nakamura CV: Effects of medicinal plant extracts on 
growth of Leishmania (L.) amazonensis and Trypanosoma cruzi. Brazilian Journal of Pharmaceutical Sciences 2005, 41:85-94.

13. Sonawane A, Santos JC, Mishra BB, Jena P, Progida C, Sorensen OE, Gallo R, Appelberg R, Griffiths G: Cathelicidin is involved in the intracellular killing of mycobacteria in macrophages. Cell Microbiol 2011, 13(10):1601-1617.

14. Kuo CC, Liu TW, Chen LT, Shiah HS, Wu CM, Cheng YT, Pan WY, Liu JF, Chen KL, Yang YN, Chen SN, Chang JY: Combination of arsenic trioxide and $\mathrm{BCNU}$ synergistically triggers redox-mediated autophagic cell death in human solid tumors. Free Radic Biol Med 2011, 51(12):2195-2209.

15. Jena P, Mohanty S, Mohanty T, Kallert S, Morgelin M, Lindstrøm T, Borregaard N, Stenger S, Sonawane A, Sørensen OE: Azurophil granule proteins constitute the major mycobactericidal proteins in human neutrophils and enhance the killing of mycobacteria in macrophages. PLoS One 2012, 7(12):e50345.

16. Mohanty S, Jena P, Mehta R, Pati R, Banerjee B, Patil S, Sonawane A: Cationic antimicrobial peptides and biogenic silver nanoparticles kill mycobacteria without eliciting DNA damage and cytotoxicity in mouse macrophages. Antimicrob Agents Chemother 2013, 57(8):3688-3698.

17. Jena P, Mohanty S, Mallick R, Jacob B, Sonawane A: Toxicity and antibacterial assessment of chitosan-coated silver nanoparticles on human pathogens and macrophage cells. Int I Nanomedicine 2012, 7:1805-1818.

18. Rastogi RP, Singh SP, Häder DP, Sinha RP: Detection of reactive oxygen species (ROS) by the oxidant-sensing probe 2',7'-dichlorodihydrofluorescein diacetate in the cyanobacterium Anabaena variabilis PCC 7937. Biochem Biophys Res Commun 2010, 397(3):603-607.

19. Cogliati M, Roverselli A, Boelaert JR, Taramelli D, Lombardi L, Viviani MA: Development of an in vitro macrophage system to assess Penicillium marneffei growth and susceptibility to nitric oxide. Infect Immun 1997, 65(1):279-284.

20. Mikusová K, Slayden RA, Besra GS, Brennan PJ: Biogenesis of the mycobacterial cell wall and the site of action of ethambutol. Antimicrob Agents Chemother 1995, 39(11):2484-2489.

21. Viveiros M, Leandro C, Amaral L: Mycobacterial efflux pumps and chemotherapeutic implications. Int J Antimicrob Agents 2003, 22(3):274-278.

22. Sonawane A, Mohanty S, Jagannathan L, Bekolay A, Banerjee S: Role of glycans and glycoproteins in disease development by Mycobacterium tuberculosis. Crit Rev Microbiol 2012, 38(3):250-266.

23. Kureel SP, Kapil RS, Popli SP: Terpenoid alkaloids from Murraya koenigii Spreng.-II. The constitution of cyclomahanimbine, bicyclomahanimbine \& mahanimbidine. Tetrahedrone Letters 1969, 44:3857-3862.

24. Handral HK, Pandith A, Shruthi SD: Review on murraya koenigii: multipotential medicinal plant. Asian Journal of Pharmaceutical and Clinical Research 2012, 5:5-14.

25. Mandal S, Nayak A, Kar M, Banerjee SK, Das A, Upadhyay SN, Singh RK, Banerii A, Banerji J: Antidiarrhoeal activity of carbazole alkaloids from Murraya koenigii Spreng (Rutaceae) seeds. Fitoterapia 2010, 81(1):72-74.

26. Tembhurne SV, Sakarkar DM: Beneficial effects of EthanolicExtract of murraya koenigii Linn. Leaves in cognitive deficit aged mice involving possible anticholinesterase and cholesterol lowering mechanism. International Journal of PharmTech Research 2010, 2(1):181-188.

27. Banerji A, Luthriya DL, Kokate SD: Toxicity of capillin, the insecticidal principle of Artemisia nilagirica Clarke. Indian J Exp Biol 1990, 28:588-589.

28. Shafi PM, Nambiar MKG, Clery RA, Sarma YR, Veena SS: Composition and antifungal activity of the oil of Artemisia nilagirica (Clarke) Pamp. JEOR 2004, 16:377-379.

29. Bishayee K, Paul A, Ghosh S, Sikdar S, Mukherjee A, Biswas R, Boujedaini N, Khuda-Bukhsh: Condurango-glycoside-A fraction of Gonolobus condurango induces DNA damage associated senescence and apoptosis via ROS-dependent p53 signalling pathway in HeLa cells. Mol Cell Biochem 2013, 382(1-2):173-183.

30. Lv L, Zheng L, Dong D, Xu L, Yin L, Xu Y, Qi Y, Han X, Peng J: Dioscin, a natural steroid saponin, induces apoptosis and DNA damage through reactive oxygen species: a potential new drug for treatment of glioblastoma multiforme. Food Chem Toxicol 2013, 59:657-669.

31. Zhang J: Transcriptome analysis reveals novel entry mechanisms and a central role of SRC in host defense during high multiplicity mycobacterial infection. PLOS ONE 2013, 8(6):01-09.
32. Li JM, Li N, Zhu DY, Wan LG, He YL, Yang C: Isocitrate lyase from mycobacterium tuberculosis promotes survival of mycobacterium smegmatis within macrophage by suppressing cell apoptosis. Chin Med J 2008, 121(12):114-119.

33. Spelman K, Burns J, Nichols D, Winters N, Ottersberg S, Tenborg M: Modulation of cytokine expression by traditional medicines: a review of herbal immunomodulators. Altern Med Rev 2006, 11(2):128-150.

doi:10.1186/1472-6882-14-87

Cite this article as: Naik et al.: Evaluation of antibacterial and cytotoxic activity of Artemisia nilagirica and Murraya koenigii leaf extracts against mycobacteria and macrophages. BMC Complementary and Alternative Medicine 2014 14:87.

\section{Submit your next manuscript to BioMed Central and take full advantage of:}

- Convenient online submission

- Thorough peer review

- No space constraints or color figure charges

- Immediate publication on acceptance

- Inclusion in PubMed, CAS, Scopus and Google Scholar

- Research which is freely available for redistribution

Submit your manuscript at www.biomedcentral.com/submit
Biomed Central 